\title{
TUBERCULOSIS IN IMMIGRANTS IN BIRMINGHAM, 1956-1957
}

\author{
BY
}

\author{
V. H. SPRINGETT, J. C. S. ADAMS, T. B. D'COSTA, AND M. HEMMING \\ From the Birmingham Chest Clinic and the Department of Social Medicine, University of Birmingham
}

Until quite recently the only numerically important migration into Great Britain was from Ireland, and the two papers (Hess and Macdonald, 1954; Brett, 1958) published since 1945 on tuberculosis in immigrants dealt mainly with tuberculosis in Irish immigrants to one section of London. The City of Birmingham, with a population of just over $1,100,000$ has many inhabitants who are not natives of the city; most have come from other parts of England, but there has also been for many years a steady immigration of Irish, and for a rather shorter period a number of Indians and Pakistanis and a considerable influx of West Indians. With this varied population and a unified tuberculosis service, it seemed appropriate to undertake at least a preliminary study of tuberculosis in immigrants in Birmingham.

It was accordingly arranged that tuberculosis visitors should routinely ascertain the place of birth of every person notified as suffering from tuberculosis in Birmingham on and after January 1, 1956.

From the information so obtained it has been possible to tabulate the place of birth, age, and sex of persons notified during the years 1956-57. It was apparent from a preliminary tabulation of the 1956 notifications that two immigrant groups, Irish and Asian born, were large enough to justify further study. The case-records of as many as possible of these patients were therefore studied to extract further information concerning date of entry to this country, type of disease, and bacteriological state. Although the cases of tuberculosis among West Indians were not numerous their records were similarly analysed, using both 1956 and 1957 cases to increase the size of the group.

Place of birth was selected as the criterion for study because the Census reports give sub-divisions of population by place of birth, and the census information is used as the basis for estimating the Irish born population of Birmingham, and for one estimate of the Asian born. For a second estimate of the Asian population and the only available estimate of the West Indian born population, we are indebted to Mr. A. Gibbs, Liaison Officer for Coloured People, City of Birmingham.

\section{6-1957 Notifications by Place of Birth}

Table I shows separately for 1956 and 1957 the numbers of persons notified as suffering from tuberculosis according to their place of birth. Notifications were 14 per cent. less in 1957 than in 1956, but with two exceptions the distribution by place of birth is very similar in the two years. The most important difference is the increase in the proportion recording Asian birth from $4 \cdot 3$ per cent to $7 \cdot 6$ per

\section{TABLE I}

PLACES OF BIRTH OF BIRMINGHAM RESIDENTS NOTIFIED AS SUFFERING FROM TUBERCULOSIS IN 1956-1957

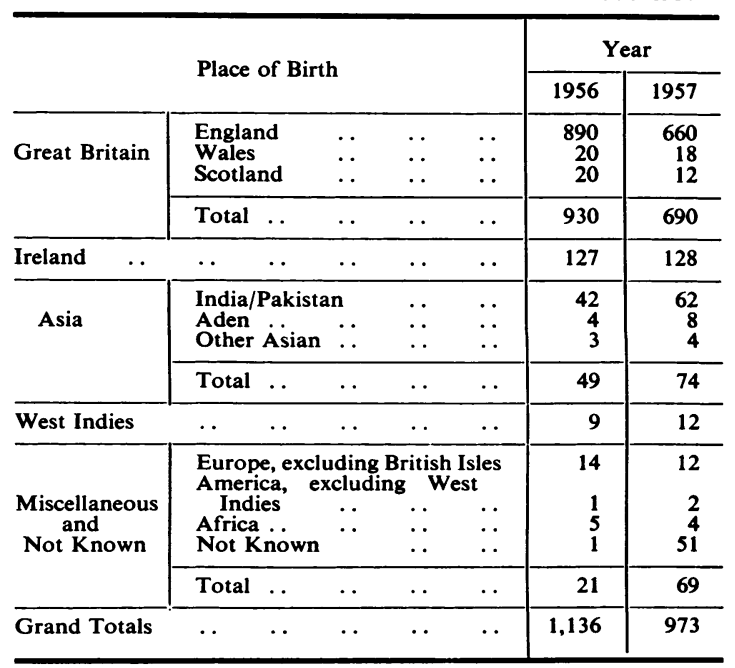


cent, with an increase in actual numbers from 49 to 78. The second difference of importance is the appearance of a group of about 5 per cent. of the total in 1957 for whom the place of birth is "not known". 1956 was the first year in which this information was collected, and it seems probable that the field-workers and clerical staff responsible were anxious to make as complete a record as possible and supplied the most probable answer when definite information was lacking. When the apparent completeness of the results became known at the end of the year, it was made clear that in subsequent years, including 1957, place of birth was to be recorded only when the information was positively available. The accuracy of the returns for the major immigrant groups (Irish, West Indian, Asian) in 1956 has been checked by subsequent studies of the medical notes and further inquiries where necessary, so that over-estimation of these groups is not possible in that year. The corrections made as a result of studying the case records, sometimes supplemented by further questioning of the patient, account for the small differences between Table I and the figures published in the report of the Medical Officer for Health for 1956.

Table I shows, as noted above, that, apart from the native born English group, the only group with large enough numbers for further study are the Irish and Asian (especially Indian/Pakistan) places of birth. The West Indians were studied as a separate group despite the small number of cases. The very small numbers recording Welsh or Scottish places of birth have been combined with those of English birth: all others and those not recorded have been taken as a final heterogeneous group.

Table II records for each of these five birth-place groups the age-sex distribution of the persons notified as suffering from tuberculosis in the years 1956-7 taken together.

As would be expected, the number of children under 15 years of age with foreign places of birth is very small indeed, and even up to age 20 years the numbers are small in the immigrant groups. The majority of notifications in immigrants occur amongst adults, and mainly amongst adults under the age of 55 years. While the notifications of those born in Ireland or the West Indies show very much the sex distribution of the native born, there are very few females amongst those recording Asian birth; at least one of the three was in fact of European parentage.

\section{Population Estimates}

IRISH BORN.-At the time of the 1951 Census there were 20,033 males and 16,316 females resident in the City of Birmingham who recorded an Irish place of birth, a total of 36,349. The figure for the county of Warwickshire (including Birmingham) was 43,575 , compared with 10,946 in the County at the 1931 Census. If the proportion of all in the County who live in the City has been constant, this suggests an annual increase of about $1,400-1,500$ in the Irish born population of the City if the increase is evenly spread over the 20 -year period. It is more probable that the increase was accelerated during the war

TABLE II

AGE-SEX DISTRIBUTION OF PERSONS NOTIFIED IN 1956-7 BY PLACE OF BIRTH

\begin{tabular}{|c|c|c|c|c|c|c|c|c|c|c|}
\hline \multirow{2}{*}{ Place of Birth } & \multirow{2}{*}{ Sex } & \multicolumn{8}{|c|}{ Age (yrs) } & \multirow{2}{*}{ Total } \\
\hline & & 0 & $15-$ & $20-$ & $25-$ & $35-$ & $45-$ & $55-$ & $\begin{array}{c}65 \text { and } \\
\text { Over }\end{array}$ & \\
\hline \multirow{2}{*}{ Great Britain } & Males & 145 & 79 & 102 & 101 & 140 & 172 & 148 & 74 & 961 \\
\hline & Females & 176 & 78 & 101 & 134 & 78 & 43 & 21 & 28 & 659 \\
\hline \multirow{2}{*}{ Ireland } & Males & 5 & 5 & 34 & 52 & 29 & 18 & 5 & 4 & 152 \\
\hline & Females & 5 & 6 & 37 & 37 & 13 & 4 & 1 & 0 & 103 \\
\hline \multirow{2}{*}{ Asia } & Males & 1 & 0 & 14 & 51 & 34 & 17 & 3 & 0 & 120 \\
\hline & Females & 1 & 1 & 0 & 1 & 0 & 0 & 0 & 0 & 3 \\
\hline \multirow{2}{*}{ West Indies } & Males & 0 & 0 & 4 & 8 & 2 & 2 & 0 & 0 & 16 \\
\hline & Females & 0 & $\mathbf{0}$ & $\mathbf{0}$ & 2 & 3 & 0 & 0 & 0 & 5 \\
\hline \multirow{2}{*}{$\begin{array}{l}\text { Miscellaneous } \\
\text { and } \\
\text { Not Known }\end{array}$} & Males & 3 & 1 & 2 & 22 & 9 & 5 & 8 & 4 & 54 \\
\hline & Females & 2 & 6 & 6 & 13 & 4 & 1 & 2 & 2 & 36 \\
\hline \multirow{2}{*}{ Totals } & Males & 154 & 85 & 156 & 234 & 214 & 214 & 164 & 82 & 1303 \\
\hline & Females & 184 & 91 & 144 & 187 & 98 & 48 & 24 & 30 & 806 \\
\hline
\end{tabular}


years and after, suggesting an increase of at least 2,000 per annum. If this has been continued since 1951 for a further 5 years there will have been a further increase of 10,000 to a total of 46,000 Irish born in 1956, and certainly 45,000 would seem the lowest likely estimate of the Irish born population in 1956-7. It is difficult to arrive at an upper limit for the Irish born population in 1956-7, but in view of the earlier rate of growth it seems unlikely to have more than doubled in 5 years after the 1951 Census, i.e. 72,000 is a probable upper limit, with a total Irish born population of between 50,000 and 60,000 as reasonably likely for 1956-7.

AsIAN BoRn.-At the 1951 Census, 2,581 males and 1,128 females resident in the City of Birmingham recorded Asian (mainly Indian/Pakistan) places of birth, a total of 3,709. The number of Asian males will certainly have increased since then, but probably not by a factor of more than 2 or 3, suggesting 5,000-7,500 males and 1,000-2,000 females of Asian birth in the City in 1956-7.

The Liaison Officer for Coloured People estimates the total population of Asian descent of adult ages at $8,000-11,000$ in $1956-7$. He regards 12,000 as an absolute upper limit to the number of adult Asian males in the City at the end of 1957.

WEST INDIAN BORN.-There were less than 500 individuals born in the West Indies in Birmingham in 1951, but from 1954 there has been a considerable immigration of West Indians into Birmingham, as into many other areas. The Liaison Officer for Coloured People estimates their number during $1956-7$ in the City of Birmingham as $20,000-25,000$ and certainly not less than 20,000 at the end of 1957.

\section{Notifications Related to Population Estimates}

The estimates of population by places of birth are subject to such large errors that it seems impracticable to calculate notification rates from them. The notification figures are known precisely, and for age and sex groups, and from these figures calculations have been made of the population from which they would have been drawn had all racial groups in the City experienced the same notification rate and using the age-sex distribution of population for Birmingham at the 1951 Census. For example, there were 81,500 males aged $25-34$ in the City at the 1951 Census, and there were 234 notifications of males of this age in 1956-7, so that for this agesex group there was one notification for every 371 of the population: the $\mathbf{5 2}$ notifications for Irish males of this age group might reasonably be drawn from a population of 19,450 . Similar calculations have been made for all other age and sex groups, and the figures so obtained are compared with the population estimate from other sources in Table III.

TABLE III

IMMIGRANT POPULATION RELATED TO POPULATION EXPECTED FROM NOTIFICATIONS

\begin{tabular}{l|c|c|c}
\hline \multicolumn{1}{c|}{$\begin{array}{c}\text { Place of } \\
\text { Birth }\end{array}$} & $\begin{array}{c}\text { Probable } \\
\text { Population } \\
\text { in 1956-7 } \\
(a)\end{array}$ & $\begin{array}{c}\text { Population from } \\
\text { which 1956-7 } \\
\text { Tuberculosis } \\
\text { Notifications } \\
\text { would be } \\
\text { Expected } \\
(b)\end{array}$ & $\begin{array}{c}\text { Ratio } \\
b: a\end{array}$ \\
\hline Ireland $\cdots$ & $45,000-70,000$ & 109,000 & $2: 1$ \\
\hline Asia $\cdots$ & $8,000-11,000$ & 45,000 & $6: 1$ to $4: 1$ \\
\hline West Indies & $20,000-25,000$ & 9,000 & $1: 2$ to $1: 3$ \\
\hline
\end{tabular}

These comparisons suggest that the notifications received for Irish and Asian born groups were in excess of what would be expected, by a factor of about 2 for the Irish born and of between 4 and 5 for the Asian born. Although the population estimates are subject to such large errors it seems fairly certain that there is an excess of notifications in these two groups, much greater in the case of the Asian group than the Irish.

There is no evidence at all of any excess of notifications amongst the West Indian group and indeed their notifications are rather less than might be expected. Again, even allowing for gross errors in the population estimates, it seems quite certain that there is no evidence of any excess of notifiable tuberculosis amongst the West Indians in Birmingham in the years under review.

There is another way of looking at the excess of notifications in the Irish and Asian born groups. The Irish notifications are about double what might be expected, and total 128 per year: this suggests that at the present time the Irish contribute about 65 excess notifications per year. The Asian notifications are about five times the expected number, with an annual average of just over sixty, suggesting about fifty excess notifications each year. These two groups together contribute an excess of about 115 cases, or about 10 per cent. of the total notifications each year.

ANAlysis of CASES occurring IN THE IRISH, Asian, AND WEST INDIAN BORN

Tables IV to VI (overleaf) give results of further study of the cases notified from these groups. In four patients, the original diagnosis of tuberculosis has 
since been revised; for a further eight no information other than the fact of notification is available-four Irish and four Asian. There remain 73 Irish males, 48 Irish females, 43 Asian males, and twenty West Indians with a confirmed diagnosis of tuberculosis; in nine males and six females from Ireland, in seven Asians, and in six West Indians the disease was nonrespiratory, i.e. one in eight Irish and one in six Asians had non-respiratory tuberculosis, as against almost one in three of the West Indians, suggesting that disseminated lesions occurred in a higher proportion of the last-named group.

TABLE IV

FURTHER CLASSIFICATION OF DIAGNOSIS OF CERTAIN BIRTH-PLACE GROUPS

\begin{tabular}{|c|c|c|c|c|}
\hline \multirow{2}{*}{$\frac{\text { Year of Notification }}{\text { Place of Birth }}$} & \multicolumn{3}{|c|}{1956} & $1956-7$ \\
\hline & \multicolumn{2}{|c|}{ Ireland } & \multirow{2}{*}{$\begin{array}{c}\text { Asia } \\
\text { Males }\end{array}$} & West Indies \\
\hline $\begin{array}{llll}\operatorname{Sex} & \ldots & \ldots & \ldots\end{array}$ & Males & Females & & $\begin{array}{l}\text { Males and } \\
\text { Females }\end{array}$ \\
\hline $\begin{array}{l}\text { Diagnosis Revised, } \\
\text { Non-tuberculous }\end{array}$ & 1 & 1 & 1 & 1 \\
\hline $\begin{array}{l}\text { Non-Respiratory } \\
\text { Tuberculosis }\end{array}$ & 9 & 6 & 7 & 6 \\
\hline $\begin{array}{l}\text { Respiratory } \\
\text { Tuberculosis }\end{array}$ & 64 & 42 & 36 & 14 \\
\hline No Information & 3 & 1 & 4 & 0 \\
\hline Totals & 77 & 50 & 48 & 21 \\
\hline
\end{tabular}

Table $\mathrm{V}$ gives a broad classification of the type and extent of disease in those with respiratory tuberculosis. The West Indians had a high proportion (one in two) with pleural effusion or hilar gland enlargement, which may reasonably be taken to indicate recent primary infections, and is in keeping with the high proportion of disseminated lesions in this group; in the other groups studied the proportion of respiratory cases with pleural effusion or hilar gland enlargement varies between one in five and one in eight. Even on the small total, the distribution of the West Indian cases is in this respect significantly different from that of any of the other three groups. Males and females of Irish birthplace have a reasonably similar distribution by type and extent of disease, but the Asians show a relatively small number with cavitated disease and a correspondingly large proportion with disease of limited extent, involving one zone or less.

Table $\mathrm{V}$ shows also the number known to have a positive sputum in each group. In the West Indians and Asians, less than half, and in Irish females about half of the respiratory cases had a positive sputum, and in the Irish males about two-thirds had a positive sputum; no information is available concerning just over half of the remainder (usually because of early return to Ireland).

Finally, in Table VI, the available information concerning the time interval between entry to this country and notification is recorded for the respiratory cases, but with rather large numbers for which this information is not available. The Irish cases had in general been in Great Britain for some time before notification; more than one in three had been in Great Britain for over 5 years, and there is

TABLE VI

DURATION OF STAY IN ENGLAND BEFORE NOTIFICATION

\begin{tabular}{|c|c|c|c|c|c|}
\hline \multicolumn{2}{|c|}{ Year of Notification } & \multicolumn{3}{|c|}{1956} & - 1956-7 \\
\hline Place of & irth & \multicolumn{2}{|c|}{ Ireland } & \multirow{2}{*}{$\begin{array}{c}\text { Asia } \\
\text { Males }\end{array}$} & West Indies \\
\hline Sex $\ldots$ & . $\quad \cdots$ & Males & Females & & $\begin{array}{c}\text { Males and } \\
\text { Females }\end{array}$ \\
\hline $\begin{array}{l}\text { Duration } \\
\text { of } \\
\text { Stay } \\
\text { (yrs) }\end{array}$ & $\begin{array}{c}-1 \\
-2 \\
-3 \\
-5 \\
-10 \\
>10 \\
\text { Not Known }\end{array}$ & $\begin{array}{r}7 \\
7 \\
6 \\
12 \\
11 \\
12 \\
9\end{array}$ & $\begin{array}{r}6 \\
9 \\
5 \\
2 \\
8 \\
11 \\
1\end{array}$ & $\begin{array}{r}10 \\
5 \\
6 \\
6 \\
4 \\
1 \\
4\end{array}$ & $\begin{array}{l}3 \\
2 \\
4 \\
2 \\
1 \\
1 \\
1\end{array}$ \\
\hline Totals & $\ldots$ & 64 & 42 & 36 & 14 \\
\hline
\end{tabular}

TABLE V

RADIOLOGICAL TYPE AND EXTENT OF DISEASE AT NOTIFICATION (RESPIRATORY CASES)

\begin{tabular}{|c|c|c|c|c|c|c|c|c|c|c|c|c|c|}
\hline \multicolumn{2}{|c|}{ Year of Notification } & . & .. & $\ldots$ & . & $\cdots$ & $\ldots$ & $\ldots$ & $\cdots$ & \multicolumn{3}{|c|}{1956} & $1956-7$ \\
\hline Place of Birth & $\cdots$ & $\cdots$ & . & $\cdots$ & . & . & $\ldots$ & $\cdots$ & $\cdots$ & \multicolumn{2}{|c|}{ Ireland } & Asia & West Indies \\
\hline Sex & $\cdots$ & $\cdots$ & . & $\cdots$ & $\cdots$ & $\cdots$ & $\cdots$ & $\cdots$ & $\cdots$ & Males & Females & Males & Males and Females \\
\hline \multirow{5}{*}{$\begin{array}{l}\text { Extent of } \\
\text { Disease }\end{array}$} & \multicolumn{3}{|c|}{ Pleural Effusion } & $\cdots$ & . & $\cdots$ & $\cdots$ & $\cdots$ & $\cdots$ & 6 & 9 & 4 & 6 \\
\hline & \multicolumn{5}{|c|}{ Hilar Glandular Enlargement } & $\cdots$ & $\cdots$ & $\cdots$ & $\cdots$ & 2 & 0 & 2 & 1 \\
\hline & \multicolumn{2}{|c|}{ No Cavity } & \multicolumn{3}{|c|}{$\begin{array}{l}1 \text { zone only } \\
>1 \text { zone }\end{array}$} & $\cdots$ & $\begin{array}{l}\cdots \\
\cdots\end{array}$ & $\because$ & $\begin{array}{l}\cdots \\
\cdots\end{array}$ & $\begin{array}{l}10 \\
14\end{array}$ & $\begin{array}{r}7 \\
12 \\
\end{array}$ & $\begin{array}{l}14 \\
12 \\
\end{array}$ & $\begin{array}{l}1 \\
3\end{array}$ \\
\hline & \multicolumn{2}{|c|}{ Cavitated } & . & $\cdots$ & $\cdots$ & $\cdots$ & $\cdots$ & $\cdots$ & $\cdots$ & 32 & 14 & 4 & 3 \\
\hline & \multicolumn{2}{|c|}{ Total } & $\cdots$ & $\ldots$ & $\ldots$ & $\cdots$ & $\ldots$ & . & $\cdots$ & 64 & 42 & 36 & 14 \\
\hline \multicolumn{3}{|c|}{ Known Sputum Positive } & $\cdots$ & $\cdots$ & $\cdots$ & $\cdots$ & $\cdots$ & $\cdots$ & $\cdots$ & 46 & 20 & 15 & 5 \\
\hline
\end{tabular}


no tendency for an accumulation of cases to occur in the first year or two after arrival; no males but three females were notified within three months of arriving in this country.

In both the Asian and West Indian groups the duration of stay in this country before notification is in general less, and a very high proportion of cases are notified within three years of arrival; this probably reflects in both groups, but especially in the West Indians, the fact that immigration of the whole group from which they are drawn is comparatively recent. However, there are differences between the Asian and West Indian groups: no West Indians were notified with three months of arrival, whereas four Asians were notified within that time, three of them with positive sputum at diagnosis; it seems reasonably certain that in these at least the disease must have been present on entry, and in these three cases the intervals between entry and $x$ ray were 1 week, 1 month, and 3 months.

\section{Discussion}

Hess and Macdonald (1954) based their study of tuberculosis in Irish immigrants on patients in five major hospitals in North-West London, a method which they realized might be subject to considerable selective factors. Their general conclusion was that the ratio of Irish patients to London patients was at least three times that expected, and attributed this mainly to the movement of a susceptible, noninfected rural population into a relatively infectious urban environment.

The present study confirms that there is more tuberculosis among the Irish born population than in the Birmingham population as a whole, but suggests that the notifications are about twice as numerous as would be expected for the general population. The factor of three times could be taken as an absolute upper limit so far as this study is concerned. The figures for duration of stay in Great Britain, type of disease, and age-sex distribution found in the Birmingham notifications agree reasonably well with those reported by Hess and Macdonald.

Brett (1958), on the basis of the proportion found to be tuberculous by mass radiography, has suggested that in parts of London at the present time there is a sevenfold excess of tuterculosis amongst the Irish born. Whilst agreeing that there is an excess in the Irish born, the Birmingham figures based on notifications do not support such a high estimate. Brett's figures show no excess of tuberculosis amongst West Indians, and here the Birmingham figures are in full agreement, and indeed suggest that the West Indian born population has relatively less tuberculosis. The types of disease that are appearing should however sound a warning-the predominance of disseminated disease and pleural effusions suggest very strongly that the immigrants from the West Indies are largely of tuberculin negative stock and are being infected for the first time after entry to this country; there may therefore be a number of later breakdowns from currently silent primary infections.

Studies of tuberculosis in migrants from Asian countries have not previously been reported, but the notification figures from Birmingham suggest that this group includes a large proportion with tuberculosis. Further, the disease is predominantly of a chronic pulmonary type, and some cases with positive sputum have been notified within a very short time of entry to this country. When these facts are taken in conjunction with the known high incidence of tuberculosis in some parts at least of India and Pakistan it seems probable that the great excess of tuberculosis in this group is due more to the migration to this country of individuals already tuberculous than to infection of susceptibles after arrival.

Finally, what measures would be most likely to lead to a reduction of tuberculosis in these immigrant groups? Workers in the tuberculosis service in Great Britain are well aware of the stringent radiographic requirements of many countries receiving emigrants from England, and it is natural to expect that similar examinations could reasonably be required of immigrants to this country. Of the twenty cases notified in Birmingham during 1956-7 from persons born in the West Indies, probably not more than three or four would have been detected by a scheme of chest $x$-ray on entry operating over the preceding 10 years. Similarly, it is possible that the majority of the Irish immigrants subsequently notified enter Great Britain tuberculin negative and with normal chest $x$ rays. In these two groups more is to be expected from B.C.G. vaccination before immigration than from routine radiography before entry. In Ireland extensive B.C.G. vaccination campaigns have been carried out, and the groups fairly completely covered while at school will soon be reaching the age at which migration tends to occur; in the long run this fact, coupled with declining opportunities for infection in the cities of this country, should lead to an adequate answer to the problem of tuberculosis in Irish immigrants to Great Britain.

The total numter of Asian born immigrants to Great Britain is fortunately small, but this group includes a very high proportion of tuberculous persons. The most likely cause for this is that they come from communities where tuberculosis is rife, 
and if so the appropriate measure is radiological examination before entry to this country. The increase in the number of notifications from this source in 1957 compared with 1956 suggests that this is a problem which is of increasing importance, and likely to be of even greater relative importance as notification rates decline in Great Britain.

\section{SUMMARY}

(1) In Birmingham in the years 1956-7 notifications of Irish born persons as tuberculous were approximately twice as numerous as would be expected from the population figures. For Asian born persons the notifications were between four and six times as numerous as would be expected. For West Indian born the notifications were rather less than would be expected.

(2) The excess in the Irish born is probably due to the migration of uninfected young adults into a relatively more infectious environment. The appropriate protective measure is B.C.G. vaccination before migration, and this is now being extensively carried out in Irish schools.

(3) From the type of disease found it is probable that the excess in the Asian born is due to the immigration of persons already having tuberculous lesions. The appropriate protective measure for Great Britain is routine radiography before entry.

We wish to thank the Medical Officer of Health, Dr. Matthew Burn, for the use of the Tuberculosis Register; Mr. Alan Gibbs, Liaison Officer for Coloured People, for assistance with population figures; and our clinical colleagues in the Birmingham Chest Service for the use of patients' records.

\section{REFERENCES}

Brett, G. Z. (1958). Tubercle, 39, 24.

Hess, E. V., and MacDonald, N. (1954). Lancet, 2, 132.

\section{AdDENDUM}

The provisional figures for notifications in Birmingham for the first half of 1958 show that the proportion of Asian born persons among those newly notified has risen still further to 9.4 per cent. The proportions of Irish born (13.8 per cent.) and West Indian born $(0.8$ per cent.) show little change from 1957. The total of notifications in the first half of 1958 is approximately 25 per cent. greater than in the first half of 1957.

Tuberculosis among immigrants from Asia is therefore a problem which continues to increase, both relatively and absolutely. 